\title{
PERBANDINGAN KINERJA KEUANGAN \\ DAN KEBIJAKAN AKUNTANSI \\ PADA PT TELKOM TbK DAN PT INDOSAT Tbk
}

\author{
HELISA NOVIARTY \\ Universitas Tanjungpura \\ ERVIN EFFENDI \\ Universitas Tanjungpura
}

\begin{abstract}
This Penelitian ini bertujuan mengetahui perbedaan kinerja keuangan dan kebijakan akuntansi antara PT Telkom Tbk dengan PT Indosat Tbk. Bentuk penelitian yang digunakan dalam penelitian ini adalah comparative research atau penelitian komparatif dengan pendekatan kuantitatif dan kualitatif. Adapun alat analisis kinerja keuangan perusahaan yang digunakan yakni rasio Profitabilitas dan Economic Value Added (EVA) sedangkan perbedaan kebijakan akuntansi berdasarkan analisa pengakuan pendapatan dan biaya yang diterapkan oleh kedua perusahaan. Hasil penelitian menunjukkan bahwa terdapat perbedaan kinerja keuangan antara PT Telkom Tbk dan PT Indosat Tbk sedangkan pada kebijakan akuntansi tidak terdapat perbedaan antara kedua perusahaan berdasarkan analisa pengakuan pendapatan dan biaya.
\end{abstract}

Keywords: Profitabilitas, Economic Value Added(EVA)

\section{PENDAHULUAN}

Perusahaan merupakan organisasi yang mencari keuntungan sebagai tujuan utamanya serta tujuan lain yang tidak kalah penting yaitu dapat terus bertahan dalam persaingan, berkembang serta dapat melaksanakan fungsi-fungsi sosial di masyarakat. Dalam pengambilan keputusan, para pelaku bisnis, membutuhkan informasi tentang kondisi dan kinerja perusahaan dengan menganalisis hubungan dari berbagai pos dalam suatu laporan keuangan diantaranya dengan menggunakan rasio-rasio keuangan. Kinerja perusahaan merupakan kata umum untuk menggambarkan keberhasilan atau kesuksesan suatu perusahaan. Kinerja yang baik menunjukkan bahwa perusahaan dikelola dengan baik. Rasio keuangan merupakan suatu teknik analisis yang dimanfaatkan sebagai alat 
ukur kondisi-kondisi keuangan sebuah perusahaan dalam periode tertentu ataupun hasilhasil usaha dari suatu perusahaan pada setiap periode. Rasio keuangan sangat membantu dalam menilai prestasi manajemen masa lalu dan prospeknya di masa depan. Rasio keuangan juga dapat memberikan indikasi apakah perusahaan memiliki kas yang cukup untuk memenuhi kewajiban finansialnya, besarnya piutang yang cukup rasional, efisiensi manajemen persediaan, perencanaan pengeluaran investasi yang baik serta struktur modal yang sehat sehingga tujuan memaksimumkan kemakmuran pemegang saham dapat tercapai.

Perusahaan telekomunikasi merupakan perusahaan yang usaha utamanya untuk mendapatkan keuntungan dengan cara menyediakan akses jaringan dan layanan telekomunikasi informatika. Terdapat beberapa perusahaan telekomunikasi yang tercatat di bursa efek atau pasar modal di Indonesia, diantaranya yang telah go-public dan mempunyai kinerja yang cukup baik dalam bidang telekomunikasi adalah PT Telkom Tbk dan PT Indosat Tbk. Selain itu, karena dalam sejarahnya kedua perusahaan tersebut merupakan perusahaan milik pemerintah sebelum akhirnya saham mayoritas PT Indosat Tbk dibeli oleh investor asing. Investor banyak yang memilih menginvestasikan dananya di pasar modal, karena keuntungan yang didapatkan lebih menjanjikan.

Menurut Pusat Informasi Go-Public Bursa Efek Indonesia (2016), perusahaan yang melakukan Public Initial Offering (IPO) atau go-public memberikan banyak keuntungan bagi perusahaan itu sendiri. Perusahaan yang telah go-public dapat membuka akses perusahaan terhadap sarana pendanaan jangka panjang. Alasan tersebut merupakan pertimbangan yang paling utama bagi perusahaan untuk melakukan go-public dan menjadi perusahaan publik. Selain itu perusahaan juga dapat meningkatkan nilai perusahaan (company value), dimana setiap publik dapat memperoleh data pergerakan nilai perusahaan sehingga setiap peningkatan kinerja operasional dan kinerja keuangan akan memiliki dampak terhadap harga saham di Bursa Efek, yang pada akhirnya akan meningkatkan nilai perusahaan secara keseluruhan.

EVA menunjukkan pengukuran yang baik sejauh mana perusahaan telah menambah nilai terhadap para pemilik perusahaan. Dengan kata lain, apabila manajeman memusatkan diri pada EVA, maka mereka akan mengambil keputusan-keputusan keuangan yang konsisten dengan tujuan memaksimumkan kemakmuran pemilik 
perusahaan (Supit, 2013). Kebijakan akuntansi dari suatu entitas pelaporan adalah prinsip-prinsip akuntansi yang spesifik dan metode-metode penerapan prinsip-prinsip yang dinilai oleh manajemen dari entitas sebagai yang paling sesuai dengan kondisi yang ada untuk menyajikan secara wajar posisi keuangan yang terjadi pada posisi keuangan dan hasil, operasi sesuai dengan prinsip-prinsip akuntansi yang berlaku umum dan karena itu telah diadopsi untuk pembuatan laporan keuangan. Pertimbangan dan atau pemilihan perlu disesuaikan dengan kondisi perusahaan. Kebijakan akuntansi berkaitan dengan pengakuan pendapatan dan biaya menarik untuk di teliti yang dimana bisa terdapat perbedaan penyajian data dan laporan keuangan jika dalam pengakuan pendapatan dan biaya yang diterapkan berbeda.

Berdasarkan latar belakang permasalahan yang diuraikan diatas, maka peneliti mengangkat judul "Perbandingan Kinerja keuangan dan Kebijakan Akuntansi di PT Telkom Tbk dan PT Indosat Tbk".

\section{KAJIAN LITERATUR}

\section{Kinerja Keuangan}

Kinerja keuangan merupakan hasil kegiatan operasi perusahaan yang disajikan dalam bentuk angka-angka keuangan (Martono dan Harjito, 2007). Kinerja keuangan merupakan salah satu ukuran yang menunjukkan efektifitas dan efisiensi pada sebuah perusahaan dalam rangka mencapai tujuannya. Bagi para investor yang melakukan analisis perusahaan, informasi laporan keuangan yang diterbitkan perusahaan merupakan salah satu jenis informasi yang paling mudah dan paling murah didapatkan dibandingkaan alternatif informasi lainnya. Disamping itu informasi laporan keuangan akuntansi sudah cukup nenggambarkan kepada kita sejauh mana perkembangan kondisi perusahaan selama ini dan apa saja yang telah dicapainya. Berikut jenis-jenis laporan keuangan yang biasa dipakai oleh investor dalam menganalisis perusahaan:

1. Neraca

Merupakan laporan keuangan yang menggambarkan kondisi finansial perusahaan pada suatu waktu tertentu. Neraca merupakan laporan tentang aktiva, kewajiban dan ekuitas pemegang saham perusahaan pada suatu tanggal tertentu. Penyusunan pos-pos yang terdapat di dalam neraca disusun berdasarkan 
urutan likuiditas (untuk aktiva) dan jangka waktu jatuh temponya (untuk pasiva). Aktiva diurutkan mulai dari yang paling likuid, sedangkan pasiva diurutkan mulai dari jatuh tempo yang paling cepat. Disebut neraca karena antara sisi aktiva dan sisi pasiva (kewajiban + ekuitas), masing-masing harus sama jumlahnya sehingga menjadi seimbang.

2. Laporan Laba Rugi

Merupakan ringkasan profitabilitas perusahaan selama periode waktu tertentu, misalnya satu tahun. Laporan rugi laba ini menunjukkan penghasilan yang diperoleh selama satu periode, biaya yang dikeluarkan selama satu periode dan elemen-elemen lain pembentuk laba. Laporan ini pada dasarnya mencerminkan perbedaan antara penghasilan dan biaya perusahaan selama periode tertentu sehingga menghasilkan keuntungan (ataupun kerugian) bersih perusahaan. Bagi investor, informasi laba yang diperoleh perusahaan bisa dijadikan dasar untuk menilai seberapa besar nilai kembalian investasi yang dilakukan (atau dikenal dengan istilah Return on Investment/ROI), atau untuk menilai seberapa besar earning yang akan diperoleh dari setiap saham yang dibeli investor (atau dikenal sebagai Earning Per Share/EPS).

3. Laporan Arus Kas

Laporan arus kas disebut juga sebagai laporan perubahan posisi finansial atau laporan aliran dana perusahaan. Laporan arus kas merupakan laporan yang memuat aliran kas yang berasal dari tiga sumber: operasi perusahaan, investasi dan aktivitas finansial yang dilakukan perusahaan. Laporan arus kas yang berasal dari operasi perusahaan menunjukkan kemampuan perusahaan dalam menghasilkan arus kas (dari operasi sehari-hari) untuk melunasi utang, pembiayaan operasi perusahaan. pembayaran dividen dan melakukan investasi baru. Aktivitas investasi dalam laporan arus kas menunjukkan pengeluaran dan penerimaan kas perusahaan yang berkaitan dengan investasi yang dilakukan perusahaan untuk menghasilkan keuntungan di masa depan. Sedangkan aktivitas finansial dalam laporan arus kas menunjukkan prediksiklaim terhadap arus kas di masa depan oleh para pemilik modal diperusahaan. 


\section{Rasio Keuangan}

Rasio keuangan sangat membantu dalam menilai prestasi manajemen masa lalu dan prospeknya di masa datang. Rasio keuangan dapat memberikan indikasi apakah perusahaan memiliki kas yang cukup untuk memenuhi kewajiban finansialnya, besarnya piutang yang cukup rasional, efisiensi manajemen persediaan, perencanaan pengeluaran investasi yang baik, dan struktur modal yang sehat sehingga tujuan memaksimumkan kemakmuran pemegang saham dapat dicapai.

Penggunaan analisis rasio keuangan sangat bervariasi dan tergantung oleh pihak yang memerlukan sesuai dengan tujuan dan harapan yang ingin dicapai (Sartono,1999:120). Misalkan supplier akan lebih menekankan pada segi jaminan yang diberikan yang ditunjukkan dengan besarnya aktiva lancar perusahaan. Pemegang saham preferen dan obligasi akan lebih menitikberatkan pada aliran kas jangka panjang. Sementara pemilik (pemegang saham) dan calon investor akan melihat dari segi profitabilitas dan risiko karena kestabilan harga saham sangat tergantung dengan tingkat keuntungan yang diperoleh dan dividen di masa datang. Bagi manajemen perusahaan akan lebih memperhatikan semua aspek analisis keuangan apakah yang sifatnya jangka pendek maupun jangka panjang, karena tanggung jawabnya untuk mengelola operasi perusahaan setiap hari dan memperoleh laba yang kompetitif . Ada lima kelompok rasio keuangan (Brigham dan Houston,2006:95), yaitu:

1. Rasio Likuiditas (Liquidity Ratios)

Rasio ini mengukur kemampuan perusahaan memenuhi kewajiban keuangan jangka pendek.

2. Rasio Manajemen Asset (Asset Management Ratios)

Rasio ini mengukur kemampuan aktiva perusahaan memperoleh laba dari operasi perusahaan.

3. Rasio Manajemen Hutang (Debt Management Ratios)

Rasio ini mengukur seberapa jauh perusahaan menggunakan hutang, mengukur kemampuan perusahaan memenuhi kewajiban keuangannya.

4. Rasio Profitabilitas (Profitability Ratios)

Rasio ini mengukur kemampuan perusahaan untuk menghasilkan laba.

5. Rasio Nilai Pasar (Market Value Ratios) 
Rasio ini dapat menunjukkan kinerja perusahaan di masa lain dan prospeknya di masa yang akan datang.

\section{Kebijakan Akuntansi}

Kebijakan akuntansi yaitu sejumlah prinsip, dasar, aturan dan praktik tertentu yang diterapkan oleh suatu entitas dalam menyusun dan menyajikan laporan keuangan. Dalam penelitian ini akan melakukan analisa terhadap pengakuan pendapatan dan biaya, karena fokus penelitian ini terdapat pada laporan keuangan yang dimana bisa terdapat perbedaan penyajian data dan laporan keuangan jika dalam pengakuan pendapatan dan biaya yang diterapkan berbeda. Dalam kebijakan akuntansi, ada beberapa hal yang diperhatikan:

\section{Pengakuan Pendapatan}

Pada prinsip pengakuan pendapatan (revenue recognation principle), umumnya pendapatan diakui pada saat direalisasikan atau dapat direalisasikan dan dihasilkan (earned). Maksud dari pernyataan tersebut adalah pendapatan dianggap direalisasikan apabila barang dan jasa, barang dagangan, atau harta lain ditukar dengan kas atau klaim atas kas; pendapatan dianggap dapat direalisasikan apabila aktiva yang diterima dalam pertukaran segera dapat konversi (siap ditukar) menjadi kas atau klaim atas kas dengan jumlah yang diketahui; pendapatan dianggap dihasilkan (earned) apabila entitas bersangkutan pada hakikatnya telah menyelesaikan apa yang seharusnya dilakukan untuk mendapat hak atas manfaat yang dimiliki oleh pendapatan itu, yakni apabila proses menghasilkan laba telah selesai atau sebenarnya telah selesai.

\section{Pengakuan Biaya}

Pengakuan biaya (expense recognition) adalah metode pencatatan biaya dalam laporan neraca laba-rugi yang terkait dengan kenyataan bahwa biaya harus diakui pada periode yang sama dengan pendapatan terkait. Jika ini tidak terjadi, biaya akan diakui pada saat terjadinya, yang mungkin mendahului atau mengikuti periode di mana jumlah pendapatan yang terkait diakui.

\section{Hipotesis Penelitian}

Hipotesis adalah jawaban sementara terhadap rumusan masalah penelitian (Sugiono, 2015). Hipotesis dalam penelitian adalah sebagai berikut: 
1. Perbedaan kinerja keuangan antara PT Telkom Tbk dan PT Indosat Tbk dihitung berdasarkan analisa rasio profitabilitas.

$\mathrm{Ho}_{1}=$ Terdapat perbedaan kinerja keuangan antara PT Telkom Tbk dan PT Indosat Tbk berdasarkan analisa rasio profitabilitas.

$\mathrm{Ha}_{1}=$ Tidak terdapat perbedaan kinerja keuangan antara PT Telkom Tbk dan PT Indosat Tbk berdasarkan analisa rasio profitabilitas.

2. Perbedaan kinerja keuangan antara PT Telkom Tbk dan PT Indosat Tbk dihitung berdasarkan Economic Value Added.

$\mathrm{Ho}_{2}=$ Terdapat perbedaan kinerja keuangan antara PT Telkom Tbk dan PT Indosat Tbk berdasarkan perhitungan EVA.

$\mathrm{Ha}_{2}=$ Tidak terdapat perbedaan kinerja keuangan antara PT Telkom Tbk dan PT Indosat Tbk berdasarkan perhitungan EVA.

\section{METODE PENELITIAN}

Bentuk penelitian yang digunakan dalam penelitian ini adalah comparative research atau penelitian komparatif dengan pendekatan kuantitatif dan kualitatif. Penelitian komparatif yakni menganalisa data dengan membandingkan antara dua variabel atau lebih terhadap suatu variabel dengan pengujian hipotesis dan data yang dipakai berupa angka-angka yang dihitung memakai metode uji statistik (Nazir, 2005). Sedangkan penelitian kualitatif ialah metode penelitian yang berlandaskan pada filsafat postpositivisme, digunakan untuk meneliti pada obyek yang alamiah, dimana peneliti adalah sebagai instrumen kunci, pengambilan sampel sumber data dilakukan secara purposive dan snowball, teknik penelitian trianggulasi (gabungan), analisis data bersifat induktif/kualitatif, dan hasil penelitian kualitatif lebih menekankan makna daripada generalisasi (Sugiyono, 2008).

Data dalam penelitian ini bersumber dari internal perusahaan. Menurut Sugiyono (2016) data internal, yaitu data yang menggambarkan keadaan atau kegiatan dalam sebuah organisasi. Data internal dalam penelitian ini diperoleh dengan cara mengunduh laporan keuangan kedua perusahaan melalui situs resmi masing-masing perusahaan yang dapat diakses melalui www.telkom.co.id untuk PT Telkom Tbk dan

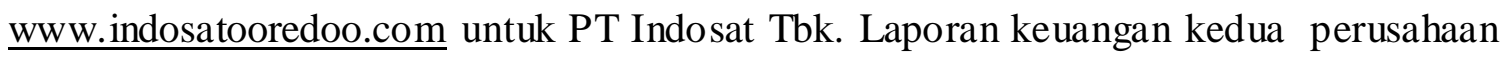


juga dapat diakses dan diunduh melalui situs resmi Bursa Efek Indonesia yang dapat diakses di www.idx.co.id.

Data dalam penelitian ini menggunakan data sekunder. Data-data diambil dan dijadikan sampel dalam penelitian ini, kemudian data-data tersebut diolah dengan menggunakan aplikasi Statistical Package for Social Science (SPSS) sehingga olahan data akan dihasilkan dalam bentuk tabel, grafik, serta kesimpulan yang berfungsi untuk mengambil keputusan atas hasil analisis. Teknik analisis data pada penelitian ini menggunakan uji statistik deskriptif, uji asumsi klasik, uji hipotesis dan analisis kualitatif komparatif.

\section{HASIL PENELITIAN DAN PEMBAHASAN}

\section{Analisa Data}

Analisis data dalam penelitian ini meliputi rasio profitabilitas, EVA dan catatan atas laporan keuangan konsolidasian pada laporan keuangan PT Telkom Tbk dan PT Indosat Tbk. Hasil uji berikut merupakan hasil data sekunder yang diolah menggunakan aplikasi SPSS (Statistical Package for Social Science) versi 25. Pada penelitian ini terdapat dua hipotesis penelitian yang akan dilakukan sebanyak tiga kali untuk menguji perbedaan ROA, NPM, dan EVA pada PT Telkom Tbk dan PT Indosat Tbk. Pengujian hipotesis menggunakan independent sample t-test dikarenakan hasil semua data skenario pada pengujian normalitas memiliki nilai signikifansi lebih besar dari 0,05 dimana data yang diolah berdistribusi normal.

\section{Uji Beda Rasio Profitabilitas PT Telkom dan PT Indosat Tbk}

Pada uji beda ini menggunakan independent sample t-test untuk menguji terdapat tidaknya perbedaan laporan keuangan PT Telkom Tbk dan PT Indosat Tbk yang dilihat melalui penilaian ROA dan NPM. Berikut hasil uji disajikan pada Tabel berikut ini: 
Tabel 4.1 Uji Beda ROA PT Telkom Tbk dan PT Indosat Tbk

\begin{tabular}{|c|c|c|c|}
\hline ROA & $\begin{array}{c}\text { Asymp. Sig. (2- } \\
\text { tailed) }\end{array}$ & $\begin{array}{c}\text { Mean } \\
\text { Difference }\end{array}$ & $\begin{array}{c}\text { Std. Error } \\
\text { Difference }\end{array}$ \\
\hline $\begin{array}{c}\text { Equal variances } \\
\text { assumed }\end{array}$ & 0,000 & 21,36400 & 1,79663 \\
\hline $\begin{array}{c}\text { Equal variances } \\
\text { not assumed }\end{array}$ & 0,000 & 21,36400 & 1,79663 \\
\hline
\end{tabular}

Sumber: Data sekunder diolah, 2019

Berdasarkan Tabel 4.1 dapat dilihat bahwa hasil uji di atas menunjukkan nilai Asymp. Sig. (2-tailed) pada perhitungan ROA bernilai lebih kecil dari 0,05 yang menggambarkan bahwa terdapat perbedaan laporan keuangan antara PT Telkom Tbk dengan PT Indosat Tbk.

Tabel 4.2 Uji Beda NPM PT Telkom dan PT Indosat Tbk

\begin{tabular}{|c|c|c|c|}
\hline NPM & $\begin{array}{c}\text { Asymp. Sig. (2- } \\
\text { tailed) }\end{array}$ & $\begin{array}{c}\text { Mean } \\
\text { Difference }\end{array}$ & $\begin{array}{c}\text { Std. Error } \\
\text { Difference }\end{array}$ \\
\hline $\begin{array}{c}\text { Equal variances } \\
\text { assumed }\end{array}$ & 0,000 & 26,15000 & 2,95920 \\
\hline $\begin{array}{c}\text { Equal variances not } \\
\text { assumed }\end{array}$ & 0,000 & 26,15000 & 2,95920 \\
\hline
\end{tabular}

Sumber: Data sekunder yang diolah, 2019

Berdasarkan Tabel 4.2 dapat dilihat bahwa hasil uji di atas menunjukkan nilai Asymp. Sig. (2-tailed) pada perhitungan NPM bernilai lebih kecil dari 0,05 yang menggambarkan bahwa terdapat perbedaan laporan keuangan antara PT Telkom Tbk dengan PT Indosat Tbk Berdasarkan perhitungan pada Tabel 4.1 dan Tabel 4.2 yang masing-masing menunjukkan hasil Asymp. Sig. (2-tailed) lebih kecil dari 0,05, sehingga dapat disimpulkan bahwa terdapat perbedaan laporan keuangan PT Telkom Tbk dan PT Indosat Tbk yang dihitung berdasarkan rasio profitabilitas.

Pada perumusan hipotesis nol $1\left(\mathrm{Ho}_{1}\right)$ yaitu terdapat perbedaan kinerja keuangan antara PT Telkom Tbk dan PT Indosat Tbk berdasarkan analisa rasio profitabilitas dan hipotesis alternatif $1\left(\mathrm{Ha}_{1}\right)$ yaitu tidak terdapat perbedaan kinerja keuangan antara PT Telkom Tbk dan PT Indosat Tbk berdasarkan analisa rasio profitabilitas. Dilihat dari 
hasil pengujian disimpulkan bahwa $\mathrm{Ho}_{1}$ diterima dan $\mathrm{Ha}_{1}$ ditolak karena menunjukkan nilai signifikansi yang bernilai lebih kecil dari 0,05 .

\section{Uji Beda EVA PT Telkom Tbk dan PT Indosat Tbk}

Pada uji beda ini menggunakan independent sample t-test untuk menguji terdapat tidaknya perbedaan kinerja keuangan PT Telkom Tbk dan PT Indosat Tbk yang dibandingkan melalui penilaian EVA. Berikut hasil uji disajikan pada Tabel 4.3 dibawah ini:

Tabel 4.3 Uji Beda EVA PT Telkom Tbk dan PT Indosat Tbk

\begin{tabular}{|c|c|c|c|}
\hline EVA & $\begin{array}{c}\text { Asymp. Sig. (2- } \\
\text { tailed) }\end{array}$ & $\begin{array}{c}\text { Mean } \\
\text { Difference }\end{array}$ & $\begin{array}{c}\text { Std. Error } \\
\text { Difference }\end{array}$ \\
\hline $\begin{array}{c}\text { Equal variances } \\
\text { assumed }\end{array}$ & 0,000 & 4,956763 & 7,069766 \\
\hline $\begin{array}{c}\text { Equal variances not } \\
\text { assumed }\end{array}$ & 0,000 & 4,956763 & 7,069766 \\
\hline
\end{tabular}

Sumber: Data sekunder yang diolah, 2019

Berdasarkan Tabel 4.3 dapat dilihat bahwa hasil uji di atas menunjukkan nilai Asymp. Sig. (2-tailed) pada perhitungan EVA bernilai lebih kecil dari 0,05 yang menggambarkan bahwa terdapat perbedaan kinerja keuangan antara PT Telkom Tbk dengan PT Indosat Tbk.Pada perumusan hipotesis nol $2\left(\mathrm{Ho}_{2}\right)$ yaitu terdapat perbedaan kinerja keuangan antara PT Telkom Tbk dan PT Indosat Tbk berdasarkan perhitungan EVA dan hipotesis alternatif $2\left(\mathrm{Ha}_{2}\right)$ yaitu tidak terdapat perbedaan kinerja keuangan antara PT Telkom Tbk dan PT Indosat Tbk berdasarkan analisaEVA. Dilihat dari hasil pengujian disimpulkan bahwa $\mathrm{Ho}_{2}$ diterima dan $\mathrm{Ha}_{2}$ ditolak karena menunjukkan nilai signifikansi yang bernilai lebih kecil dari 0,05.

Perbedaan Kinerja Keuangan antara PT Telkom Tbk dan PT Indosat Tbk Berdasarkan Perhitungan Rasio Profitabilitas

Berdasarkan hasil pengujian hipotesis pertama dan kedua membuktikan bahwa terdapat perbedaan kinerja keuangan antara PT Telkom Tbk dan PT Indosat Tbk. Hal ini ditunjukkan dari hasil pengujian yang menunjukkan nilai signifikansi pada analisa ROA sebesar 0,000 dan pada analisa NPM sebesar 0,000 yang lebih kecil dari $\alpha 0,05$. Oleh karena itu, ditarik kesimpulan bahwa terdapat perbedaan kinerja keuangan antara PT 
Telkom Tbk dan PT Indosat Tbk karena hasil pengujian menunjukkan hipotesis diterima pada kedua analisis rasio profitabilitas. Hasil temuan ini sesuai dengan hasil temuan Ulum, Mardani, dan Wahono (2017), namun berbeda dengan temuan Yupit (2000) yang menyatakan ROA dan NPM menunjukkan tidak ada perbedaan kinerja keuangan pada laporan keuangan kedua perusahaan. Dengan demikian, untuk laporan keuangan kedua perusahaan yang dianalisis berdasarkan rasio profitabilitas dinilai terdapat perbedaan kinerja keuangan antara PT Telkom Tbk dan PT Indosat Tbk.

Perbedaan Kinerja Keuangan antara PT Telkom Tbk dan PT Indosat Tbk Berdasarkan Perhitungan EVA

Berdasarkan hasil pengujian hipotesis ketiga membuktikan bahwa terdapat perbedaan kinerja keuangan antara PT Telkom Tbk dan PT Indosat Tbk. Hasil pengujian menunjukkan nilai signifikansi pada perhitungan EVA yaitu sebesar 0,000 dimana nilainilai tersebut lebih kecil dari $\alpha$ 0,05. Demikian ditarik kesimpulan bahwa terdapat perbedaan kinerja keuangan antara PT Telkom Tbk dan PT Indosat Tbk karena hasil pengujian menunjukkan hipotesis diterima pada perhitungan EVA.Hal yang sama juga dikemukakan Ulum, Mardani, dan Wahono (2017) yang menyebutkan EVA pada PT Telkom Tbk lebih baik dari PT Indosat Tbk. Hal itu disebabkan oleh laba bersih operasi setelah pajak PT Telkom Tbk yang lebih tinggi dari biaya modal setelah pajak. Tetapi pada temuan Yupit (2017) mengemukakan dugaan perbedaan EVA yang signifikan terhadap kinerja keuangan pada PT Telkom Tbk dan PT Indosat Tbk tidak terbukti. Dengan demikian, untuk laporan keuangan kedua perusahaan yang dianalisis berdasarkan perhitungan EVA dinilai terdapat perbedaan kinerja keuangan antara PT Telkom Tbk dan PT Indosat Tbk.

Perbedaan Kebijakan Akuntansi antara PT Telkom Tbk dan PT Indosat Tbk

\section{Berdasarkan Analisa Pengakuan Pendapatan dan Biaya}

Dalam penelitian ini dilakukan analisa terhadap pengakuan pendapatan dan biaya, karena fokus penelitian ini terdapat pada laporan keuangan yang dimana bisa terdapat perbedaan penyajian data dan laporan keuangan jika dalam pengakuan pendapatan dan biaya yang diterapkan berbeda. Berdasarkan hasil analisa komparatif terhadap pengakuan pendapatan dan biaya antara PT Telkom Tbk dan PT Indosat Tbk menunjukkan bahwa tidak terdapat perbedaan kebijakan akuntansi. Kedua perusahaan mempunyai kebijakan 
akuntansi yang sama yakni pada tahun 2014 dan 2015 dimana terdapat 4 poin pengakuan (Pendapatan telepon seluler, Pendapatan Hubungan Keagenan, Pendapatan Program loyalitas pelanggan dan Pendapatan Interkoneksi) dan 1 poin pengakuan biaya yang dibandingkan dengan hasil memiliki kebijakan akuntansi yang sama. Pada tahun 2016, 2017, dan 2018 terdapat 4 poin (Pendapatan telepon seluler, Pendapatan Multipleelement arrangements, Pendapatan Hubungan Keagenan, dan Pendapatan Program loyalitas pelanggan) dan 1 poin pengakuan biaya yang dibandingkan dengan hasil memiliki kebijakan akuntansi yang sama.

\section{SIMPULAN}

Berdasarkan hasil analisa perbedaan kinerja keuangan dan kebijakan akuntansi antara PT Telkom Tbk dan PT Indosat Tbk berdasarkan rasio profitabilitas dan EVA serta catatan atas laporan keuangan konsolidasian yang telah diuraikan sebelumnya, maka ditarik kesimpulan sebagai berikut:

1. Terdapat perbedaan kinerja keuangan pada pada PT Telkom Tbk dan PT Indosat Tbk, hal ini ditunjukkan dari hasil perhitungan rasio Profitabilitas (ROA dan NPM) serta EVA yang menunjukkan hasil Asymp. Sig. (2-tailed) lebih kecil dari 0,05.

2. Tidak Terdapat Perbedaan Kebijakan akuntansi pada PT Telkom Tbk dan PT Indosat Tbk, hal ini ditunjukan dari hasil analisa catatan atas laporan keuangan konsolidasian dari tahun 2014-2018.

\section{REFERENCES}

Efriyanti, Farida, Retno Anggraini, dan Yunus Fiscal. (2012). Analisis Kinerja Keuangan Sebagai Dasar Investor dalam Menanamkan Modal pada PT Bukit Asam Tbk (Studi Kasus pada PT Bukit Asam Tbk). Jurnal Akuntansi dan Keuangan. Vol. 3, No. 2, hal. $299-316$.

Ghozali, I. (2013). Aplikasi Analisis Multivariate dengan Program IBM SPSS 21. Edisi 7. Semarang: Badan Penerbit Undip.

Harahap, Sofyan S. (2013). Analisis Kritis Atas Laporan Keuangan, Cetakan Kesebelas. Jakarta: Penerbit Rajawali Pers.

Hidayat, Anwar. (2013). Penjelasan Rumus Kolmogorov Smirnov Uji Normalitas. Diakses dari https://www.statistikian.com/2013/01/rumus-kolmogorovsmirnov.html pada tanggal 30 September 2018.

Horne, James C. Van dan John M Wachowicz. (2007). Prinsip-prinsip Manajemen Keuangan. Edisi 12, Buku 2. Bandung: Salemba Empat. 
Irawati, S. (2006), Manajemen Keuangan. Bandung: Pustaka.

Kasmir. (2008). Bank dan Lembaga Keuangan Lainnya. Jakarta: Rajawali Pers.

Kindangen, Claudia Friska. (2016). Analisis Perbandingan Kinerja Keuangan pada Perusahaan Telekomunikasi yang Terdaftar di Bursa Efek Indonesia Periode 2011 - 2014 (Studi Kasus pada PT Telekomunikasi Indonesia Tbk dan PT XL Axiata Tbk). Jurnal Berkala Ilmiah Efisiensi. Vol. 16, No. 3.

Lontoh, R. D., Marjam Mangantar, dan Yunita Mandagie. (2017). Analis is Perbandingan Kinerja Keuangan PT HM Sampoerna Tbk dan PT Gudang Garam Tbk Periode 2011-2014. Jurnal EMBA. Vol. 5, No. 2, hal. 393 - 403.

Martono dan Harjito (2007). Manajemen Keuangan, Edisi Pertama, Cetakan Keenam. Yogyakarta: Ekonisia.

Mulyadi. (2001). Balanced Scorecard Alat Manajemen Kontenporer untuk Pelipatganda Kinerja Keuangan Perusahaan. Jakarta: Salemba Empat.

Nazir, Moh. (2005). Metode Penelitian. Bogor: Ghalia Indonesia.

Pangestika, Widya. (2018). Cara Menilai Kinerja Perusahaan dengan Rasio Keuangan. Diakses dari https:/jurnal.id/id/blog/2018-cara-menghitung-rasiokeuangan-untuk-menilai-kinerja-perusahaan// pada tanggal 3 Oktober 2019.

Pusat Informasi Go Public Bursa Efek Indonesia. (2016). Diakses dari https $/ /$ gopublic.idx.co.id, pada tanggal 2 Oktober 2019.

Rivai, Veithzal et all. (2007). Bank and Financial Institution Management. Jakarta: PT Raja Grafindo Persada.

Rudianto, Dudi. (2011). Analisis Perbandingan Kinerja Keuangan PT Telkom Tbk dengan PT Indosat Tbk Periode 2005 - 2010. Bussiness and Management Review. Vol. 2 No. 1.

Russilawati, Rista. (2018). Analisis Perbandingan Kierja Keuangan Bank Umum Konvensional dengan Bank Umum Syariah di Indonesia Periode 2012-2016 Menggunakan Metode RGEC. Fakultas Ekonomi Universitas Negeri Yogyakarta: Yogyakarta.

Sawir, Agnes. (2005). Analisis Kinerja Keuangan dan Perencanaan Keuangan Perusahaan. Jakarta: Gramedia Pustaka Utama.

Sekaran, Uma. (2006). Metodologi Penelitian untuk Bisnis 1. Edisi 4. Jakarta: Salemba Empat.

Situs Resmi PT Indosat Tbk. www.indosatooredoo.com.

Situs Resmi PT Telekomunikasi Indonesia Tbk. www.telkom.co.id.

Suad, Husnan dan Enny Pudjiastuti. (2006). Dasar-dasar Manajemen Keuangan. Edisi 5. Yogyakarta: UPP STIM YKPN.

Sudarmaji dan Sularto. (2007). Pengaruh Ukuran Perusahaan Profitabilitas, Laverage, dan Tipe Kepemilikan Perusahaan Terhadap Luas Voluntary Disclosure Laporan Keuangan Tahunan. Jurnal Penelitian. Fakultas Ekonomi Universitas Gunadarma. Jakarta.

Sugiyono. (2010). Metode Penelitian Kuantitatif Kualitatif dan R\&D. Bandung: Alfabeta.

Sugiyono. (2016). Metode Penelitian Kuantitatif Kualitatif R\&D Cetakan ke 23. Bandung: Aflabeta.

Supit, Yolanda. (2013). Perbandingan Kinerja Keuangan PT Telkom Tbk dan PT Indosat Tbk Tahun 2006-2011. Jurnal EMBA. Vol. 1, No. 4, hal. 116 - 126. 
Ulum, Hafidzul, Ronny M. Mardani, dan Budi Wahono. (2017). Analisis Perbandingan Kinerja Keuangan Perusahaan Telekomunikasi yang Tercatat di BEI (Studi Kasus pada PT Telekomunikasi Indonesia Tbk dan PT Indosat Tbk Periode 2006 2015). E-Jurnal Riset Manajemen. Fakultas Ekonomi Universitas Islam Malang: Malang. 